\title{
Om jalousitemaet hos Proust
}

\section{Kærligheden dekonstrueret}

Jalousitemaet har en helt central plads i Prousts værk fra begyndelse til ende. Den sidste tekst i debutbogen fra 1896, novellesamlingen Les Plaisirs et les jours (Glæder og dage), har endda titlen "La fin de la jalousie" ("Jalousiens ophør"). Hvordan jalousien ophører eller kan ophøre, er også et vigtigt spørgsmål i På sporet af den tabte tid, som Proust på et tidspunkt overvejede at kalde Les Intermittences du cour (Hjertets omskiftelser). I novellen ophører jalousien, da den jaloux dør, men i På sporet er den lige besættende længe efter, at den elskede har forladt denne verden (dette er en central tematik i Albertine forsvundet). I Prousts hovedværk lader det til, at der kun er to måder, jalousien kan ophæves på: ved langvarig adskillelse eller ved et kedeligt samliv, hvor vanen og hverdagens rutiner dræber begæret og spontaniteten (den første af disse udgange bliver fremhævet i Albertine forsvundet, begge to i Swanns kærlighedshistorie). Hvor vigtigt spørgsmålet om jalousiens ophør end er i Prousts univers, giver han spørgsmålet om jalousiens årsag og betydning endnu større opmærksomhed, og det er på dette punkt, han demonstrerer sin psykologiske originalitet.

Jalousitemaet er selvfølgelig nært knyttet til kærlighedstematikken, men i dette tilfælde fremstilles forbindelsen ikke helt som forventet: Proust skruer lidt på den sædvanlige opfattelse, som går ud på, at jalousi forudsætter kærlighed, altså at man skal være forelsket eller elske for at blive jaloux. Sådan er det ikke nødvendigvis, siger han og mener, at forholdet lige så vel kan være omvendt. Således er, eller bliver, flere af hans personer jaloux, før de elsker. Det er her jalousien, som skaber, fremkalder eller afføder den følelse, vi almindeligvis kalder kærlighed, og som de fleste af os associerer med emotionel tilknytning eller nærhed indtil afhængighed. Hos Proust starter tilknytningen med jalousi. ${ }^{.}$Dette er ikke helt så underligt, som det umiddelbart kan synes, for jalousi er ofte i sig selv en emotionel tilknytning, som kan udvikle sig til afhængighed. Og ligesom jalousien generelt er possessiv og kontrollerende, kan man ofte sige det samme om kærligheden. Jalousi og kærlighed har 
desuden det grundliggende til fælles, at de begge har indbygget angsten for at miste et andet menneske, som man føler man har behov for, som man af og til føler, man ikke kan leve uden, eller - lidt mindre positivt - som man gerne vil eje med hud og hår og sjæl og sind. Det sidste er meget udbredt hos Proust. Dét er netop hovedårsagen til, at grænsen mellem jalousi og kærlighed er så flydende i hans univers.

Kærlighedsforhold i almindelig forstand findes der ikke mange af i På sporet. Vel kan vi sige, at Prousts fortæller, et par gange også kaldet Marcel, elsker sin mor og sin mormor, som også elsker ham tilbage. Og måske elsker den homoseksuelle baron Charlus i en periode den unge violinist Morel. Men gensidig, voksen kærlighed er så godt som fraværende. Der kan nok være spirer til den, men jalousien, som kærligheden altså er uadskillelig fra, hindrer den konsekvent i at blive en positiv livskraft. Generelt ødelægges den af den mandlige hovedpersons ekstreme narcissisme, som skaber en uoverstigelig afgrund mellem fantasi og virkelighed; mellem drøm, længsel og begær efter total besiddelse og kontrol på den ene side, og virkelige personer og relationer som aldrig helt lader sig kontrollere på den anden side.

Både Prousts fortæller og Swann er til og med psykologisk afhængige af den fundamentale modsætning mellem imaginært og reelt liv, og af den frustration og lidelse som med nødvendighed følger af den. De gange de føler, at fantasierne, og særligt fantasien om den andens totale underkastelse, er, eller er i færd med at blive, realiseret, sådan at afstanden mellem drøm og virkelighed truer med at blive ophævet, mister den elskede og forholdet til hende al tiltrækningskraft. For de narcissistiske hovedpersoner er en urealiseret fantasi langt at foretrække for realiseringen af den. Det betyder, at lidelsen er vigtigere for deres livsførelse end det, der i drømmen fremstår som lykken. Realiseret lykke fører i Prousts verden straks til kedsomhed. Når fortælleren i korte perioder kan siges at opleve lidenskab, er det altid i ordets dobbelte betydning, den konventionelle og den etymologiske: som begær kombineret med lidelsen over at begæret ikke lader sig realisere, eller at det ikke opleves som gengældt. Nicolas Grimaldi skriver om det narcissistiske begærs paradoksale karakter hos Proust: “1) Man elsker kun det, man ikke besidder. 2) Vor kærlighed er afhængig af vore lidelser. 3) Man holder op med at begære det, man tror er umuligt at miste" (Grimaldi 2008, 167). Ifølge den narcissistiske logik er det helt afgørende, at jalousien hele tiden destabiliserer forhold, som ser ud til at kunne give varig lykke. Det er et kendetegn ved jalousien, siger Grimaldi, at den opretholder forestillingen om, at den elskedes intime og trygge nærvær er forbigående eller utilfredsstillende. Hun lader som om, hun er her, men i realiteten er hun altid allerede et andet sted, er den jaloux' tanke (Grimaldi 2008, 172).

Jalousien er således ikke nødvendigvis kun destruktiv, men kan også have en dynamiserende effekt på parforholdet. Jean Baudrillard, som stiller forførelsen, forstået som et gensidigt og ligeværdigt erotisk spil, over kærligheden, er også inde på dette. Han hævder, at der altid er et element af jalousi i kærligheden, og at det kan skyldes, at jalousien går forud for kærligheden, som den gør hos Proust. Måske er jalousien en "oprindelig lidenskab", tænker han, "sådan som hos de græske guder, som hverken kender kærligheden eller er sentimentale, men som alligevel er voldsomt jaloux på hinanden" (Baudrillard 1983, 147-148). I forlængelse af Baudrillard kunne vi sige, at jalousien også kan forhindre kærligheden i at stivne, det vil sige i 
at tabe enhver forbindelse med forførelsen. Problemet i Prousts værk er ikke desto mindre jalousiens narcissistisk-paranoide karakter.

Grimaldis analyser af jalousi og kærlighed i På sporet er spændende, men det er overraskende, at han stadig bruger ordet "kærlighed" om de emotionelle forbindelser, Prousts fortæller skildrer og dissekerer. Ordet "kærlighed", og særlig det franske amour, har jo for de fleste positive konnotationer, ikke mindst i den franske kontekst, hvor det blandt andet giver associationer til Stendhals romantiske klassiker De l'amour. Der kaldes i øvrigt jalousien "det største af alle onder” (Stendhal 2011, 1:152). Det, vi er vidne til hos Proust, er en dekonstruktion af det dominerende, romantiske kærlighedsbegreb. Derfor er det også forbavsende, at Grimaldi helt sammenblander Marcel, Swann og Proust selv som jalousiens subjekt, og at han endog uden markering udskifter deres navne med henholdsvis "vi”, "man" og "jeg”. Således giver han indtryk af, at han fuldstændig identificerer sig med kærlighedssynet i På sporet, og af at han vil have, at vi, hans læsere, også skal gøre det, fordi det er alment sandt. Men dette indebærer at ophøje paranoid, sygelig jalousi til universel norm.

Det er netop identificerende læsninger af Grimaldis type, Philippe Chardin distancerer sig fra i Proust-kapitlet i sin afhandling om jalousi-temaet i moderne europæisk litteratur. Allerede i første afsnit advarer han således mod kun at lade sig nøje med at parafrasere fortællerens tanker om jalousi, hvor besnærende de end kan være, for selv om fortælleren demonstrerer stor almen-psykologisk indsigt, er hans selvforståelse ikke altid den bedste (Chardin 1990, 135). En svaghed ved Chardins egen analyse er imidlertid, at den bliver lidt for generel og ufokuseret, selv om den er fuld af gode observationer.

Ellers lægger hverken Grimaldi eller Chardin megen vægt på den påfaldende nedtoning af seksualitetens rolle i skildringen af forholdet mellem fortælleren og Albertine, idet det er vigtigere for Marcel at herske psykisk over sin kæreste, end det er at eje hende fysisk.

Jeg ønsker ikke her at inddrage den gamle diskussion om, hvorvidt skildringerne af heteroseksuelle relationer i På sporet måske egentlig er transpositioner af Prousts egne homoseksuelle forhold. Jeg mener tværtimod, at der hele vejen er en analytisk distance mellem forfatteren Marcel Proust og fortælleren Marcel. Det har været hævdet, at Albertine i virkeligheden skulle være en forklædt udgave af Prousts chauffør og elsker Alfred Agostinelli. Men kun at opfatte skildringen af forholdet mellem Marcel og Albertine som en kamufleret fremstilling af forholdet mellem Proust selv og Alfred er litterært set lige så urimeligt som at reducere Roland Barthes' Fragments d'un discours amoureux (Kærlighedens forrykte tale) til bag facaden primært at handle om Barthes' eget homoseksuelle kærlighedsliv - uden at de to forfatteres seksuelle orientering nødvendigvis er helt irrelevant.

\section{Digter og psykolog}

De dele af På sporet, som kommer mest ind på jalousi-temaet, er Swanns kærlighedshistorie, Fangen og Albertine forsvundet (oprindeligt La Fugitive (Flygtningen)). Men Combray er også vigtig, for det er der, vi finder en psykologisk forklaring på fortælle- 
rens konstante jalousi, som bunder i en angst for at blive forladt - en angst som det ikke ville være helt forkert at kalde patologisk. Det forhindrer ikke, at Proust som få andre får kernen i al jalousi frem, for den er til syvende og sidst kærlighedslængslen. Det utålelige kontrolbehov og den egocentriske trang til at eje, som ofte definerer jalousien på en ekstrem måde hos Proust, er hovedsagelig mere eller mindre perverterede udtryk for længslen efter kærlighed. ${ }^{2}$

Når denne længsel så ofte får forvrængede udslag, og altså ikke mindst i sygelig jalousi med destruktive følger, skyldes det måske selve den romantiske kærlighedsopfattelse, som hersker i vores kulturkreds. Flere psykologer har taget denne problemstilling op, blandt andre Aaron Ben-Ze'ev og Ruhama Goussinsky i en bog med den sigende titel In the Name of Love. Romantic Ideology and its Victims (2008). Ifølge det, de kalder den romantiske ideologi, er kærligheden sammensmeltning, en fusion, af to bevidstheder, men selv om en sådan fusion er idealet, er den i virkeligheden en umulighed. En god filosofisk begrundelse for, hvorfor en bevidsthedssammensmeltning ikke kan blive mere end en ønskedrøm, giver Sartre i Væren og Intet (L'Être et le Néant), med reference til Proust:

64 Hvis kærlighed faktisk var rent begær efter fysisk besiddelse, kunne den i mange tilfælde let tilfredsstilles. Prousts helt, for eksempel, som indlogerer sin elskerinde hos sig, kan se og besidde hende på alle tider af døgnet og har vidst at bringe hende i en total materiel afhængighed af sig, burde ikke have grund til bekymring. Man ved dog, at han tværtimod er plaget af bekymring. Det er i kraft af sin bevidsthed, at Albertine unddrager sig Marcel, selv når han er ved hendes side, og det er derfor, han kun har ro i sindet, når han betragter hende, mens hun sover. Det er altså sikkert, at kærligheden vil fange "bevidstheden". (Sartre 2013, 432)

Sartre påpeger noget helt afgørende, når han skriver, at den elskende vil elskes tilbage af "en frihed", samtidig med at han eller hun paradoksalt "forlanger at denne frihed som frihed ikke længere er fri" (ibid., 433). Der er meget få forfattere som både demonstrerer og analyserer denne problematik tydeligere og mere skånselsløst end Proust. Som nævnt tror mange, at han identificerer sig totalt med sin fortæller så vel som med Swann. Men der kan ikke være tvivl om, at der findes en ubarmhjertig, analytisk distance i På sporet, og at den har både en filosofisk, en psykologisk og en etisk dimension. Distancen kommer til udtryk gennem selve fortællingen, men den formuleres også eksplicit i form af forfatterkommentarer. I Swanns kærlighedshistorie læser vi således, at Swann begyndte at forstå, "hvilket vanvid det var der havde grebet ham [da han] var begyndt at hige efter at eje et andet menneske, som om det var muligt" (Swanns verden 2, 260). Det er måske nok Swanns selverkendelse, at det er og forbliver umulig at eje et andet menneske fuldstændigt, men det kritiske perspektiv er mere fundamentalt fortællerens, og bag det utvivlsomt Prousts eget.

Det er også utilladeligt reducerende for enhver pris at ville tilbageføre Prousts analytiske fremstilling af jalousiens beskaffenhed og konsekvenser til eksisterende psykologisk eller psykoanalytisk teori. Proust er en analytisk autoritet i egen ret. Således er jeg enig med Harold Bloom, når han skriver at "the Proustian account of jealousy is very much Proust's own" (Bloom 1995, 397), selvom Bloom ikke desto 
mindre overdriver forskellen på romanforfatterens og psykoanalytikerens jalousiforståelse. Både Proust og Freud er mindre optaget af det, Freud kaldte den normale jalousi, end af den sygelige, ud fra den forståelse, at de ekstreme varianter også siger noget væsentligt om den almindelige, som vi alle kender. ${ }^{3}$

Noget som klart adskiller Proust fra såvel Freud som andre professionelle psykologer og psykoanalytikere er imidlertid, at han som romanforfatter kan sætte jalousien ind i konkrete livssammenhænge, som han nok har skabt selv, men som dog er realistiske. Det er karakteristisk, at når psykologer ønsker at komme ud over almindeligt etablerede indsigter, må også de gøre rede for enkeltpatienters konkrete livssammenhænge, hvis de da ikke går til digterne for at hente illustrerende historier. ${ }^{4}$ Proust slipper for det, for han er psykolog og digter i én og samme person.

\section{Det ødipale substrat}

I Fangen har Marcel inviteret den unge pige Albertine til at bo hos sig i Paris. Han er nogen år ældre end hende, men han er også ung. De har mødt hinanden i feriebyen Balbec på den normandiske kyst, hvor hun har tilbragt to sommerferier med fire andre teenagepiger. At netop Marcel og Albertine bliver et par forekommer relativt tilfældigt, for han vakler længe, før han slår ned på hende. Vi kan heller ikke sige, at han egentlig elsker hende. Ikke desto mindre bliver han helt afhængig af hende og fra første stund voldsomt jaloux.

I flere passager i Fangen bliver der henvist til episoder fra Marcels barndom, beskrevet i første bind, Combray, og hver gang bliver det understreget, at Albertine har en psykologisk funktion i hans nuværende liv, som minder om den funktion, moderen havde i hans barndom. Sagt på en anden måde, og mere konkret: Der kan ikke herske nogen tvivl om, at Marcel er styret af, og lider under, et aldrig tilstrækkeligt bearbejdet Ødipuskompleks. Hans Ødipuskompleks er ikke blevet "likvideret”, som franske psykoanalytikere siger. Jeg skal give nogle citater fra Fangen, som viser dette med al tydelighed.

Det første citat lyder således:

46 Når jeg i dag tænker på at min veninde efter vores hjemkomst fra Balbec havde slået sig ned i Paris under samme tag som jeg, at hun havde givet afkald på tanken om at tage på krydstogt, at hendes værelse lå tyve skridt fra mit eget for enden af gangen, i min fars gobelinværelse, og at hun meget sent hver aften før hun forlod mig, smuttede sin tunge ind i min mund som et dagligt brød, [...], er det jeg straks bliver mindet om som sammenligningsgrundlag, [...] den [nat] hvor min far sendte min mor op at sove i den lille seng ved siden af min. (Fangen 1, 6)

I sin bog Freud, Proust and Lacan hævder Malcolm Bowie med rette, at Proust og Freud tænkte forskelligt om menneskepsykens natur, idet Proust forudsætter at "the mind is transparent from level to level and permeable part by part", mens Freud "offers us models of the mind in which barriers and opacities may occasionally be attenuated but never definitively removed" (Bowie 1987, 71). ${ }^{5}$ På en friskere og frækkere måde påstår Harold Bloom, at "Freud is Proust's rival, not his master [...]. 
Applying Freud to Proust on jealousy is as reductive and misleading as analyzing Search's vision of homosexuality in a Freudian way" (Bloom 1995, 397). Pierre Chardin mener på sin side, at fremstillingen af jalousiens ophav i På sporet peger mindre mod Freud og hans begreb om Ødipuskomplekset end mod Melanie Klein og hendes begreb om en oprindelig misundelse (envy) i barnets forhold til moren (Chardin 1990, 145-46). Ikke desto mindre deler Proust og Freud tydeligvis den opfattelse, at mandens forhold til moderen i barndommen er afgørende for hans emotionelle og seksuelle udvikling:

$46 \mathrm{p}$ når jeg snakkede med min mor, snart som min bedstemor talte til mig. [...] På den måde blandede min fortid fra de tidligste år og hinsides disse mine slægtninges fortid en på samme tid sønlig og moderlig ømheds sødme med min urene kærlighed til Albertine. (Fangen 1, 99-100)

64 Desværre blev det en af de aftener hvor denne lindring ikke blev bragt mig, hvor det kys som Albertine ville give mig før hun gik, var meget anderledes end hendes sædvanlige kys og ikke ville give mig mere lindring end min mors før i tiden når hun var vred, og hvor jeg ikke turde kalde hende tilbage, men hvor jeg følte at jeg ikke ville kunne falde i søvn. (Ibid., 111)

46 Som om alle mine følelser der rystede af skræk for ikke at kunne beholde Albertine ved min seng både som elskerinde, som søster, som datter, også som en mor der siger godnat hver aften, og som jeg atter begyndte at føle en barnlig længsel efter [...] Hvert minut bragte mig nærmere det godnat fra Albertine som hun omsider sagde. Men denne aften efterlod hendes udeltagende og flygtige kys mig i en så angstfyldt tilstand at jeg med bankende hjerte iagttog hende gå hen mod døren mens jeg tænkte: "Hvis jeg vil finde et påskud til at kalde hende tilbage, holde på hende, slutte fred, må jeg skynde mig, hun har kun få skridt tilbage før hun er ude af værelset, kun to, kun et, hun drejer håndtaget, hun åbner, det er for sent hun har lukket døren bag sig!” Men måske alligevel ikke for sent. Ligesom før i tiden i Combray når min mor havde forladt mig uden at have beroliget mig med sit kys, ville jeg styrte efter Albertine, jeg følte at jeg ikke ville få fred før jeg havde set hende igen. (Ibid., 144-145)

Vi må uden overdrivelse kunne sige at Marcels ubearbejdede Ødipuskompleks og den angst for ikke at blive elsket og for at blive forladt, som følger med det, har gjort ham særdeles disponeret for jalousi.

Swann i Swanns kærlighedshistorie lider også under en voldsom angst for at blive forladt. Han må i så henseende kaldes Marcels alter ego, eller måske hans tvillingesjæl. Lad os nøjes med dét som forklaring på det lidt usandsynlige forhold, at Marcel er i stand til at fortælle om Swanns liv, sådan som det udspandt sig længe før, han selv var født, og dét ikke bare med indlevelse, men også med indgående kendskab til hans intime tanke- og følelsesliv. ${ }^{6}$ 


\section{Angsten og jalousien går forud for kærligheden}

Charles Swann, med det britiskklingende navn, er en forfinet intellektuel som i lighed med de fleste andre af Prousts personer klart tilhører overklassen. Nøjagtig hvor gammel han er i Swanns kærlighedshistorie, får vi ikke vide, men det bliver sagt, at han ikke længere er helt ung. Jeg gætter på, at han er i 30-årsalderen et sted, sandsynligvis nærmere 40 end 30. Vigtigere er det, at han er livstræt og blasert indtil det kyniske med mange kærlighedshistorier bag sig og uden illusioner om, at der venter ham nye. De kvinder, der stadig interesserer ham, er ikke nogen, der kunne blive et passende parti for ham i henhold til hans sociale stand og intellektuelle niveau, men overvejende simple ungpiger fra folkedybet, som betager ham med deres friskhed og det, man i hans kredse kalder et vulgært udseende.

Odette, den kvindelige hovedpersonen i Swanns kærlighedshistorie og snart Swanns kæreste, er også bag facaden enkel og vulgær, men hun har i flere år gjort det til sit levebrød at fremstå som en anden end den, hun egentlig er. Hun har været en luksusprostitueret af den type, franskmændene kalder en kokotte og formåede at blive gift med en pengestærk mand med det adelige navn de Crécy. Odette, som er fraskilt, da Swann tilfældigt bliver præsenteret for hende en aften i teatret, er derfor helt uden den uskyldige friskhed, som han almindeligvis er ude efter. Når Swann alligevel bliver besat af hende, skyldes det til at begynde med mindre ham end hende. Fra første stund er det nemlig hende, som er den aktive. Hun inviterer sig selv hjem til ham og smigrer ham med skønne ord om hans gode smag og hans intelligens, og fremfor alt introducerer hun ham med held i Madame Verdurins salon, hvor hun selv i længere tid har vært en selvskreven gæst.

Swann vægrer sig imidlertid for at tilbringe hele aftenen i denne borgerlige salon under hans egen sociale rang. I stedet gør han det til en vane at dukke op efter middagen og bare blive hængende en tid, for derefter at følge Odette hjem. Det bliver et ritual som de begge to sætter pris på, og som, hvad enten han vil eller ej, fører dem nærmere hinanden. En aften sker der noget hos Madame Verdurin, som styrker båndet mellem dem yderligere: Sammen hører de en ung pianist spille andante-partiet af en vidunderlig sonate for violin og klaver af den ukendte komponist Vinteuil (som er identisk med en spillelærer i Combray, hvis datter fortælleren vil komme til at kende). Denne sonate, der ofte omtales i På sporet, bliver "deres kærligheds kendingsmelodi", for efter denne fælles musikoplevelse, som fornys flere gange, er det umuligt for Swann at forestille sig livet uden Odette: Han bliver gradvis afhængig af hende, og hun bliver vigtigere for ham end nogen anden kvinde.

Men igen er forelskelse og kærlighed hos Proust underordnet den possessive jalousi. For når Swann regelmæssigt kommer til Verdurins salon og tager Odette med i sin vogn, er det ikke for at tilbringe natten med hende, og ikke engang for at afslutte aftenen i erotisk intimitet, sådan som hun mere end tydeligt inviterer ham til. Det er nok for ham at vide, at hun ikke har en anden mandlig ven eller elsker, som hun foretrækker frem for ham. For når han bringer hende hjem sent på aftenen, kan hun vanskeligt finde anledning til et nyt stævnemøde, efter at han er kørt hjem til sig selv. Swann har altså et stort kontrolbehov over for Odette. Og det viser sig, som jeg allerede har antydet, at det er angst for at blive forladt, som ligger til grund for hans ejetrang. Det er overvejende en psykologisk trang, for sine seksuelle behov 
tilfredsstiller han parallelt hos andre, mindre betydningsfulde kvinder. Swann tilbringer regelmæssigt første del af aftenen sammen med "en lille arbejderpige", som han bliver ved med at hygge sig med også i tiden efter, at Odette er blevet uundværlig for ham.

Men han ender med at drive sit dobbeltspil for langt. En aften kommer han med vilje senere end sædvanligt til Verdurins, fordi han havde taget sin "lille arbejderpige" med ud til Boulogneskoven for at forlænge samværet med hende. Og så er Odette der ikke længere! Hun er gået! Reaktionen er voldsom:

46 Dad

Da det gik op for Swann at hun ikke længere var til stede i salonen, følte han et stik i hjertet; han rystede ved tanken om at gå glip af en glæde hvis omfang han nu for første gang gjorde sig klart. (Swanns verden 2, 62)

Besat af angst og jalousi drager han ud i det natlige Paris for at finde hende. Men hun er ikke i den restaurant, hvor hun havde sagt til Madame Verdurin, at hun ville gå hen, og hun er heller ikke til at opdrive på andre populære spisesteder. Swann giver alligevel ikke op, og hans jagt bliver mere og mere frenetisk, drevet af en desperation, som definitivt forsegler hans kærlighed. Vi må unde os fortællerens nøgterne forklaring på dette:

46 Af alle de måder kærligheden kan opstå på, og af alle de smittekilder der kan sprede den hellige sygdom, er ingen så virkningsfuld som det sus af sindsbevægelse der undertiden går igennem én. Så er terningerne kastet, så bliver den man i netop det øjeblik nyder at være sammen med, også den man kommer til at elske. (Ibid., 69)

I vognen på vej hjem, efter at Swann til sidst har fundet Odette spadserende på gaden, kommer de fysisk i berøring med hinanden på en mere intim måde end før og tilbringer så resten af natten sammen - for første gang. Efter dette er Swanns jalousi-kærlighed endnu mere intens end tidligere.

Der er al grund til at gentage, at jalousien bunder i en ødipalt defineret angst for at blive forladt. Samtidig kunne vi også kalde jalousien en speciel form for klarsyn, eller intuition. Som det fremgår mod romanens slutning, er Odette nemlig hele tiden sammen med andre mænd, i særdeleshed en grev de Forcheville, som hun gifter sig med i sit tredje ægteskab, efter at Swann er død. Så den angst, som i begyndelsen af romanen fremstår som irrationel, viser sig til slut ikke at være helt grundløs. Dette forhindrer ikke, at angsten også er en drivkraft helt uden behov for ydre legitimering i form af beviselig utroskab.

En anden episode bidrager på en speciel måde til at intensivere Swanns angstdeterminerede jalousi.

Han har deltaget i en festmiddag uden Odette, og hun har været i Verdurins salon uden ham. Men lidt over kl. 23 tænker han, at han vil tage hendes ord om, at hun altid vil være til stede for ham, alvorligt, og han beder kusken køre ham til hendes adresse. Imidlertid er hun mindre imødekommende over for ham end sædvanligt og gør ham straks opmærksom på, at om senest en time må han gå sin vej, fordi hun har hovedpine og vil lægge sig tidligt. Hun afviser ham derfor, da han ytrer øn- 
ske om erotisk kontakt: "Du kan vel nok se at jeg har det dårligt!" (ibid., 129), siger hun bryskt. Da han er kommet hjem til sig selv, begynder han imidlertid at tænke lidt over hendes adfærd og indser med ét, at hun måske bare ville have ham væk for at kunne modtage en anden mand, hun havde lavet en aftale med. Ængsteligt tager han derfor tilbage til Odettes hus og ser, at der er lys. Det overbeviser ham om, at han havde ret i sin mistanke, og jalousien slår naturligvis ud i fuldt flor. Det viser sig imidlertid, at han i farten har udset et forkert hus, for bag vinduet befinder der sig slet ikke nogen Odette med en hemmelig elsker, men derimod et par ældre herrer. Et hændeligt uheld, med andre ord.

Ikke desto mindre bliver Swann ved med at være på vagt, og han finder stadig gode grunde til, at det er helt nødvendigt. Og jalousien gælder ikke bare den nævnte greve, men udvikler sig snart til en form for generaliseret paranoia:

Han besluttede sig til at fjerne Odette fra Forcheville og tage hende med nogle dage til Sydfrankrig. Men han troede at alle mænd på hotellet havde lyst til hende, og at hun også selv begærede dem. Og derfor oplevede man at han, som altid når han var ude at rejse før i tiden, havde søgt at lære nye mennesker at kende og var færdedes i store forsamlinger, nu var blevet menneskesky og undgik at omgås andre som om deres selskab sårede ham grusomt. Og hvordan skulle han også kunne undgå at blive misantrop når han i hver eneste mand så en mand der muligvis kunne blive Odettes elsker? (Ibid., 146)

Hvor paranoid Swann end er, har hans jalousi alligevel stadig et vist grundlag i virkeligheden. For det bliver tydeligere og tydeligere, at Odette hverken elsker eller er forelsket i ham længere. Hun finder derfor forskellige påskud for at få tid både for sig selv og sammen med andre, hun fortier og hun lyver - og tager på. Men parallelt med at hun manifesterer sin ligegyldighed over for ham og bliver tykkere og mindre pæn, bliver hun bare endnu mere dyrebar for Swann, noget hun udnytter med stadig større kynisme. Således "levede Swann i det pinefulde sindsoprør som allerede havde været stærkt nok til at få hans kærlighed til at folde sig ud den aften hvor han ikke havde truffet Odette hos Verdurins og havde ledt efter hende hele aftenen" (ibid., 162). Han fortsætter med andre ord med at leve i en tilstand af konstant jalousi. Eller rettere: Der kommer til at gå endnu et godt stykke tid, før jalousien holder op med at plage ham. Når det til slut sker, er det interessant, at det ikke fører til, at han bryder med hende, sådan som vi kunne have ventet, men tværtimod til at de gifter sig.

Swann tænker først, at den bedste chance for en ændring af hans til tider uudholdelige eksistentielle situation, domineret af angst og jalousi, er, at Odette slet og ret dør - "ved et ulykkestilfælde, uden at lide" (ibid., 247). Men så kommer han på en anden løsning, som nok engang understreger, hvor ukonventionelt kærlighedssynet i På sporet er. Han tænker nemlig, at "hvis han kunne have mødt hende uden pauser, ville hans smerte i det mindste med tiden blive dulmet og hans kærlighed måske ende med at dø" (ibid.). Swann "havde mistet alt håb om nogensinde at vinde hendes kærlighed" (ibid., 248), og derfor gælder det om, at også han på sin side skal holde op med at elske Odette, noget han mener kan ske, hvis han bare får anledning til at være så meget sammen med hende, at vanen og kedsomheden tager 
jalousiens, smertens og længslens plads og erstatter det, han definerer som kærlighed.

Det som reelt sker, er, at hun drager ud på en længere rejse, som varer næsten et helt år, og at Swanns følelser for hende forandrer sig radikalt i løbet af denne tid. I stedet for at længes efter, at hun skal komme tilbage, og i stedet for at bekymre sig om, hvilke eventyr hun kunne tænkes at kaste sig ud i på rejsen, føler han sig efterhånden rolig, "næsten lykkelig" (ibid., 274). Han har endelig fået hende ud af systemet, som det hedder. Den "Odette der havde vakt hans kærlighed og jalousi, den Odette der voldte ham smerte, og som han nu aldrig mere ville få at se" (ibid., 280).

Romanens konklusion er skånselsløs og fortjener at blive citeret, hvor velkendt Swanns afsluttende udråb end er:

Uf Han så atter [...] Odettes alt for magre kinder, hendes blege teint, de hærgede træk, de sorte rande under øjnene, alt det som han - i løbet af de mange gentagne forelskelser i deres årelange kærlighedshistorie, der havde kastet et glemslens slør over hans første indtryk af hende - var holdt op med at lægge mærke til efter deres første tid sammen [...] Og med den periodiske flabethed der dukkede op så snart han ikke længere var ulykkelig, og hans moralske normer samtidig dalede, udbrød han for sig selv: "At tænke sig at jeg har spildt år af mit liv, at jeg har ønsket at dø, at jeg haft min største kærlighedshistorie med en kvinde, som jeg ikke brød mig om, som ikke var min type!" (Ibid., 285)

Sådan ender Swanns kærlighed, og med den hans jalousi. Eller omvendt: Sådan ender hans jalousi, og dermed hans kærlighed. Under normale omstændigheder ville vi derfor tro, at han nu endelig havde styrke til at forlade Odette, som han egentlig bare foragter. Men som sagt er det ikke det, der sker. Tværtimod er det først nu, i visheden om at han aldrig mere kan elske hende, at Swann bestemmer sig for at gifte sig med Odette og gøre hende til en ærbar kvinde. I Prousts Paris i sidste halvdel af det 19. århundrede, hvor de aristokratiske traditioner lever videre, er en ærbar kvinde en, som er gift med en velstående mand, som ikke elsker hende, og som hun heller ikke elsker.

I lyset heraf er det interessant at se, hvordan kærlighedshistorien mellem Albertine og fortælleren, Marcel, ender. For også den slutter.

\section{Kun tiden kan læge jalousiens sår}

Marcel er mindst lige så jaloux som Swann, og det, som trigger hans jalousi allermest, ja, gør den til et helt vanvittig behov for kontrol, er mistanken om, at Albertine har haft, og stadig, mens hun bor med ham i Paris, har, forhold til andre kvinder. Hun lyver eller tier om disse forhold, noget Marcel dels aner, dels kan konstatere, hvilket gør ham endnu mere ude af sig selv.

Som filosoffen Emmanuel Lévinas har påpeget, lyver hun imidlertid for at overleve som selvstændig person i forholdet til den jaloux Marcel, som ikke bare er ekstremt kontrollerende, men også autoritær, selvgod og manipulerende (Lévinas 
sin lille flig af frihed eller i det mindste følelse af frihed, så Marcel ikke får fuldstændig magt over hende.

Det bryder han sig ikke om, og efter en tid siger han til hende, at de bør afbryde forholdet, og at hun skal flytte ud af hans lejlighed. Men fuldstændig afhængig af hende som han er blevet, mener han det ikke inderst inde. Chokket er derfor stort, da Albertine tidligt en morgen, før han er vågnet, har taget ham på ordet og er rejst sin vej til sin tante i Touraine. Men selv om Marcel således mister taget i hende, og selv om hun begynder et nyt liv langt borte fra ham, hvilket tvinger ham til at reorientere sig, opgiver han hende alligevel ikke. Det betyder, som altid hos Proust, at jalousien varer ved.

Den følelsesmæssige afhængighed af Albertine og afhængigheden af jalousien selv er endog to sider af samme sag. At jalousien er et eget psykologisk behov og en egen psykologisk drivkraft viser sig på en speciel måde i Albertine forsvundet, det bind som følger efter Fangen. Her er Albertine ikke bare rejst sin vej, hun dør også. Og jalousien overlever både Albertines opbrud og hendes død. Marcels besatte trang til at få ALT at vide om HELE hendes liv er mindst lige så stor efter, at hun er borte, som den var, mens hun var i live.

Slipper jalousien så aldrig taget i fortælleren? Jo, til sidst gør den - sammen med kærligheden.

Groft sagt er det tiden, som svækker hans følelsesmæssige binding til Albertine. Da han modtager et falskt brev, som giver indtryk af, at hun alligevel ikke er død og til og med er villig til at genoptage samlivet med ham, reagerer Marcel derfor med stor distance og næsten kynisk ligegyldighed:

64 Nu hvor Albertine ikke længere levede i mine tanker, gav nyheden om at hun var i live mig ikke den glæde, jeg havde forestillet mig. For mig havde Albertine blot været et bundt tanker, hun havde overlevet sin materielle død så længe disse tanker levede i mig; men nu var disse tanker til gengæld døde, og Albertine genopstod på ingen måde for mig med sin krop. (Albertine forsvundet, 310-11)

Med Marcels selvanalyse sætter jeg punktum i denne sammenhæng.7 Hans pessimistiske budskab må være, at ingen kærlighed varer evigt, og at den dør samtidig med jalousien, fordi jalousien er kærlighedens vigtigste drivkraft. Vi er langt hinsides alle forestillinger om kærligheden som ligeværdigt venskab, som varm omsorg, som en jævn strøm af spontan glæde over et kontinuerligt samvær bygget på berigende kommunikation, fælles hus og hjem og barn. Den højborgerlige Proust er en radikal forfatter.

Oversat af Mads Anders Baggesgaard

\section{Noter}

I Dette uddybes af Nicolas Grimaldi i hans Essai sur la jalousie. L'enfer proustien, 2010.

2 For Julia Kristeva er had, og først og fremmest selvhad, en væsentlig dimension ved jalousien både hos Proust og generelt. Hvor psykoanalytisk abstrakt og fortættet hendes analyse end er, tror jeg alligevel ikke, at hendes forståelse af Swann og Marcel er grundlæggende forskellig fra 
min og fra Grimaldis. For også hun lægger vægt på den jaloux’ outrerede narcissisme, som reducerer den begærede kvinde til en imaginær konstruktion uden holdepunkt i virkeligheden. Dermed er den jaloux' begær dømt til aldrig at kunne opfyldes med frustration, foragt og selvforagt, had og selvhad som uundgåelig konsekvens. Ifølge Julia Kristeva er der alligevel en vigtig forskel mellem Swann og fortælleren i Prousts værk, fordi fortælleren formår at sublimere begæret gennem skabende, litterær fiktion (se underkapitlet “Jalouser et écrire”, Kristeva 1994, 40-47).

3 Se Freuds artikel "Some neurotic mechanisms in Jealousy, Paranoia and Homosexuality" [1922] (Freud 1971). Freud bruger udtrykket "rivaliserende jalousi" i samme betydning som "normal jalousi".

4 Psykiatere taler eksempelvis om "Othello-syndromet" (se Langfeldt 1972, 7). Daniel Lagache, som i en periode stod Lacan fagligt nær, argumenterer i sin store jalousiafhandling fra 1947 for det, han kalder "den beskrivende psykologi" (la psychologie descriptive), som han selv repræsenterer, og som netop lægger vægt på at analysere jalousien som en integreret del af hele patientens livspraksis (se Lagache 1981, 718).

5 Se også kapitlet "Proust, jealousy, knowledge" i samme bog (46-65).

6 Der er nogle eksempler på, at fortælleren forklarer sin indsigt i Swanns følelsesliv med, at han har fået indblik i det senere: “Jeg tænkte at Swann nok ville have blæst på de angstfyldte øjeblikke jeg netop havde gennemlevet, [...] men, som jeg senere skulle erfare, havde en lignende angstfyldt uro tværtimod plaget ham i mange år af hans liv, og der var måske ingen anden der bedre ville kunne have forstået mig end ham. For ham var det kærligheden der havde gjort ham bekendt med den uro man føler, når man véd at den man elsker er ude at more sig et sted hvor man ikke selv er, og hvor man ikke kan komme, den kærlighed som en sådan uro på en måde er forudbestemt til, og som en dag vil beslaglægge den og gøre den til sit specielle felt" (Swanns verden 1,44$)$.

7 Jalousi-temaet hos Proust vil jeg også behandle i en bog, jeg har givet arbejdstitlen Ekstreme fortellinger. Om sykelig sjalusi i psykologi og litteratur (udkommer efter planen i 2016).

\section{Litteratur}

Barthes, Roland (1985): Kærlighedens forrykte tale [1977], oversat af Karen Nicolajsen, København: Rævens sorte bibliotek.

Baudrillard, Jean (1983): Les Stratégies fatales, Paris: Grasset.

Ben-Ze'ev, Aaron og Ruhama Goussinsky (2008): In the Name of Love. Romantic Ideology and its Victims, Oxford: Oxford University Press.

Bloom, Harold (1995): The Western Canon. The Books and School of the Ages [1994], London: Papermac.

Bowie, Malcolm (1987): Freud, Proust and Lacan. Theory as fiction, Cambridge: Cambridge University Press.

Chardin, Philippe (1990): "De l'amour-jalousie chez Proust", i L'Amour dans la haine, ou la jalousie dans la littérature moderne : Dostoïevski, James, Svevo, Proust, Musil, Genève: Droz.

Freud, Sigmund (1971): "Some neurotic mechanisms in Jealousy, Paranoia and Homosexuality" i James Strachey (ed.): The Standard Edition of the Complete Psychological Works of Sigmund Freud, bd. XVIII, [1955], London: The Hogarth Press and the Institute of Psycho-Analysis, s. 223-232.

Grimaldi, Nicolas (2008): Proust, les horreurs de l'amour, Paris: Presses universitaires de France. 
Kristeva, Julia (1994): Le Temps sensible. Proust et l'expérience littéraire, Paris: Gallimard.

Lagache, Daniel (1981): La Jalousie amoureuse. Psychologie descriptive et psychanalyse [1947], Paris: Presses universitaires de France.

Langfeldt, Gabriel (1972): Sjalusisyken, Oslo: Aschehoug.

Lévinas Emmanuel (1976): "L'autre dans Proust" [1947], i Noms propres, Paris: Fata Morgana, s. 117-23.

Proust, Marcel (2002-2014): På sporet af den tabte tid, 13 bd., København: Multivers.

Sartre, Jean-Paul (2013): Væren og intet - Et essay om fænomenologisk ontologi [1943], oversat af Mogens Chrom Jacobsen, Aarhus: Philosophia.

Stendhal (2011): Om kærligheden [1822], 3 bd., oversat af Karsten Sand Iversen, København: Basilisk. 